Pak. j. sci. ind. res. Ser. A: phys. sci. 201255 (2) 80-85

\title{
Proximate Composition and Functional Properties of Dehulled African Nutmeg (Monodora myristica)
}

\author{
Henry Niyi Ogungbenle* and Tosin Oluwakemi Adu \\ Department of Chemistry, Ekiti State University, P.M.B. 5363, Ekiti State, Nigeria
}

(received March 24, 2011; revised June 2, 2011; accepted June 22, 2011)

\begin{abstract}
The proximate composition and functional properties of dehulled African nutmeg (Monodora myristica) were determined. Crude protein, ash, fat and fibre contents were: $14.67 \%, 2.27 \%, 24.06 \%$ and $30.04 \%$, respectively. Gelation concentration was $4 \%$. Water and oil absorption were $160 \%$ and $256 \%$, respectively. The emulsion capacity and emulsion stability were $45.6 \%$ and $42 \%$ while the foaming capacity and foaming stability were $50.0 \%$ and $4 \%$, respectively. Minimum solubility was observed at $\mathrm{pH} 4.0$ and maximum, at $\mathrm{pH} 10$. Total essential and total non-essential amino acids amounted to the average values of $48.4 \%$ and $51.60 \%$, respectively.
\end{abstract}

Keywords: African nutmeg, proximate composition, functional properties, amino acid

\section{Introduction}

African nutmeg (Monodora myristica) belongs to the family Ananacea; it is a climber tree, grows well in the evergreen forests of West Africa and is most prevalent in the southern part of Nigeria (Adegoke and Akinsanya, 1970). Investigations reveal that almost every part of the tree has economic importance. However, the most economically important part is the seed which is embedded in a white sweet-smelling pulp. On an average, 119-122 seeds can be found in one fruit (Okon, 1983). The harvesting period is between April to September. Various processing methods such as fermentation, washing, drying and cracking are employed before consumption or storage (Ejiofor et al., 1998). It is used to make a popular condiment for souring. It is also used in the treatment of mild fever and as a diuretic; and as an antiseptic (Fagbemi and Oshodi, 1991). The objective of this work is to evaluate proximate, amino acid composition and functional properties of dehulled African nutmeg (Monodora myristica) seeds.

\section{Materials and Methods}

The African nutmeg (Monodora myristica) was obtained from old Garage market in Ado-Ekiti, Ekiti State, Nigeria. The seeds were screened and the good ones were later dehulled, sun dried and then dry-milled into flour and kept in freezer for the analyses.

The proximate analysis of the sample for total ash, moisture, crude fibre and ether extract was carried out using the method of AOAC (2005). Nitrogen content

\footnotetext{
*Author for correspondence; E-mail :httphenryo@yahoo.com
}

was determined by micro Kjeldahl method (Pearson, 1976) and was converted to crude protein by multiplying by 6.25 . Carbohydrates were determined by the method of difference i.e.

$\{100$-(ash + moisture + crude protein + crude fibre + ether extract)\}.

All tests were carried out in triplicate.

The method described by Sathe et al. (1982) was used to determine gelation property with slight modification and that described by Beuchat (1977) for water and oil absorption capacities. The emulsion capacity and stability were determined as stated by Inklaar and Fortuin (1969) while foaming capacity and stability as by Coffmann and Garcia (1977). The protein solubility as a function of $\mathrm{pH}$ was determined according to AOAC (2005) and the graph of protein solubility against $\mathrm{pH}$ was plotted using the data obtained.

For amino acid profile, the sample was dried to constant weight, defatted using soxhlet extractor and hydrolysed in sealed glass ampoule at $105^{\circ} \mathrm{C} \pm 5^{\circ} \mathrm{C}$ for $22 \mathrm{~h}$ using $7 \mathrm{~mL}$ of $6 \mathrm{M} \mathrm{HCl}$ (Spackman et al., 1958). The hydrolysate was evaporated in a rotary evaporator and loaded into the Technicon sequential multisample amino acid analyser (TSM, Taryton, USA).

\section{Results and Discussion}

Proximate composition. Proximate composition of dehulled African nutmeg, $M$. myristica, is presented in Table 1. The sample had high level of crude fibre (3.04\%) and low ash content (2.27\%). The average crude protein 
(14.67\%) was higher than that of millet (11.4\%) reported by Oshodi et al. (1999), but lower than those of lima bean flour (22.7\%; Oshodi and Adeladun, 1993) and of pigeon (22.4\%; Oshodi and Ekperigin, 1989). Thus dehulled African nutmeg, $M$. myristica, has higher protein content and somewhat more balanced amino acids than those of the most of cereals e.g. millet and sorghum (Oshodi et al., 1999). It can be inferred from this result that African nutmeg can be used as supplement to foods that have higher amounts of carbohydrate but low protein content (Ogungbenle, 2003). It is also a very cheaper source of protein than animal products like meat, fish, egg etc. Protein is responsible for the repairs of worn-out tissues and body building. The crude fibre content of African nutmeg was 3.04\% which is very high. It is higher than those of pigeon pea (3.8\%) reported by Oshodi and Ekperigin (1989) and cowpea (2.6\%; Aletor and Aladetimi, 1989), pearl millet (3.1\%; Oshodi et al., 1999), cooked walnut (3.03\%; Ogungbenle, 2009), gourd seed (2.80\%; Ogungbenle, 2006) and groundnut cake (2.7\%; Oyenuga, 1968). Dietary fibre has a number of beneficial effects related to indigestibility in the small intestine (Asp, 1996). Therefore, the high value of fibre content of African nutmeg can improve the digestibility and the absorption processes in the large intestine. It has an ash content of $2.27 \%$ which is comparable to that of sorghum flour (2.29\%; Awadalkareem et al., 2008) and higher than that of wheat flour (1.50\%; Ahmed et al., 2008). The ash content of African nutmeg is lower than the value for scarlet runner bean flour (4.71\%) and those of bambara groundnut (4.30\%; Aremu et al., 2005), cowpea (3.7\%; Olaofe et al., 1994), soy bean (4.12\%; Temple et al., 1991) and milk powder (4.70\%; Ahmed et al., 2008).

The moisture content of African nutmeg was $11.11 \%$ (Table 1). This value is favourable as compared to that of scarlet runner bean flour (10.96\%; Aremu et al., 2005) and lima bean (12.0\%; Oshodi and Adeladun, 1993) but higher than that of kidney bean(8.80\%; Olaofe et al., 2010). This implies that African nutmeg has good shelf life, since it has low level of moisture and will not allow the growth of microorganisms.

The fat content of African nutmeg (24.06\%) is lower than the value obtained for groundnut (43.0\%) and Calabash seeds (43.0\%) as reported by Apata and Ologhobo (1994). However, it is higher than that of scarlet runner bean (10.85\%; Aremu et al., 2005) and soy bean (18\%; Paul and Southgate, 1988).
The carbohydrate content of African nutmeg is $17.85 \%$. This value is higher than those of pumpkin flour (6.93\%; Fagbemi and Oshodi, 1991) and gourd seed (9.89\%; Ogungbenle, 2006; Olaofe et al., 1994), scarlet runner bean (48.36\%; Aremu et al., 2005), Terminalia catappa (16.02\%; Nzikou et al., 2010) and kidney bean (40.0\%; Olaofe et al., 2010). This shows that African nutmeg is also a better source of energy like scarlet runner bean.

Table 2 presents the functional properties of dehulled African nutmeg. The water absorption capacity (160\%) is higher than those of lima bean (142.2\%; Oshodi and Adeladun, 1993), soy flour (130\%; Lin et al., 1974), lupin seed (120\%; Sathe et al., 1982) fluted pumpkin seed flour (85\%; Fagbemi and Oshodi, 1991) and dehulled Afzelia africana seeds (128.31\%; Ogungbenle and Omaejalile, 2010). This indicates that African nutmeg is suitable for the production of gravies.

The oil absorption capacity of African nutmeg is $256 \%$ which is higher than those of wheat and soy flours with values of (84.2\%) and (84.4\%), respectively as reported by Lin et al. (1974) and some Nigerian oil seeds like conophor nut (108.13\%; Ige et al., 1984) and Bombacopsis glabra (91.8\%; Olaofe et al., 2006), but lower

Table 1. Proximate composition of dehulled African nutmeg (M. myristica)

\begin{tabular}{ll}
\hline \hline Component & $\%$ \\
\hline Ash & 2.27 \\
Moisture & 11.11 \\
Crude protein & 14.67 \\
Fat & 24.06 \\
Crude fibre & 3.04 \\
Carbohydrate by difference & 44.85 \\
\hline \hline
\end{tabular}

Table 2. Functional properties of dehulled African nutmeg (M. myristica)

\begin{tabular}{ll}
\hline \hline Parameters & $\%$ \\
\hline Water absorption capacity(WAC) & 160.0 \\
Oil absorption capacity(OAC) & 256.0 \\
Emulsion capacity(EC) & 45.6 \\
Emulsion stability(ES) & 42.0 \\
Foaming capacity(FC) & 50.0 \\
Foaming stability (FS) & 4.0 \\
Least gelation concentration (\%W/V) & 4.0 \\
\hline \hline
\end{tabular}


than that of cowpea flour (281-321\%; Olaofe et al., 1994). This high value of oil absorption capacity makes African nutmeg a better flavour retainer and improves the mouth feel of foods (Kinsella, 1976).

The emulsion capacity (45.6\%) was higher than those of African yam bean dehulled seed flour (10.0-20.0\%; Oshodi et al., 1997), soy flour (18.0\%; Lin et al., 1974) and dehulled Afzelia africana seeds (35.25\%; Ogungbenle and Omaejalile, 2010). The emulsion stability of African nutmeg (42\%) is highly comparable to that of pigeon pea (49.40\%; Oshodi and Ekperigin, 1989) and quinoa flour (45.0\%; Ogungbenle, 2003). This implies that African nutmeg may be useful as a food additive/extender, for binder formulation and for stabilization of colloidal foods.

The value of least gelation concentration of African nutmeg $(4 \% \mathrm{~W} / \mathrm{V})$ is low when compared to other seed legumes such as lupin seed flour $(14 \% \mathrm{~W} / \mathrm{V}$; Sathe et al., 1982), great northern bean seed flour (10\% W/V; Sathe and Salunkhe, 1981), pigeon pea flour (12\% W/V; Oshodi and Ekperigin, 1989) and dehulled Afzelia africana $(6.00 \% \mathrm{~W} / \mathrm{V}$; Ogungbenle and Omaejalile, 2010) but higher than the value of B. glabra flour (2.0\% W/V; Olaofe et al., 2006). This low value of dehulled African nutmeg may be an asset in its use as an additive to other gel forming materials in food products.

The foaming capacity and stability of dehulled African nutmeg are $50 \%$ and $4 \%$, respectively. The former is low when compared to that of soy flour (68\%) and sunflower (600\%) as reported by Lin et al. (1974) and that of pigeon pea flour (68\%; Oshodi and Ekperigin, 1989). The foaming stability of African nutmeg (4\%) is lower than that of soy flour (14.6\%) and sunflower flour (9.0\%; Lin et al., 1974) but higher than those of quinoa flour (2.0\%; Ogungbenle, 2003) and 3.0\% for dehulled A. africana (Ogungbenle and Omaejalile, 2010).

Figure 1 shows the variation of protein solubility of African nutmeg with $\mathrm{pH}$. It indicates minimum protein solubility at $\mathrm{pH} 4$ and maximum protein solubility at $\mathrm{pH} 10$. The minimum value of $\mathrm{pH} 4.0$ is comparable with that of cowpea protein (Olaofe et al., 1994).

It is also comparable with African yam bean (Oshodi et al., 1997) with minimum solubility at $\mathrm{pH} 4.5$ moth bean (Sathe et al., 1982) and full fat fluted pumpkin seed flour (Fagbemi and Oshodi, 1991) while lower than those scarlet runner bean flour (pH 5.0; Aremu et al., 2006) and pigeon pea (pH 5.0; Oshodi and Ekperigin,

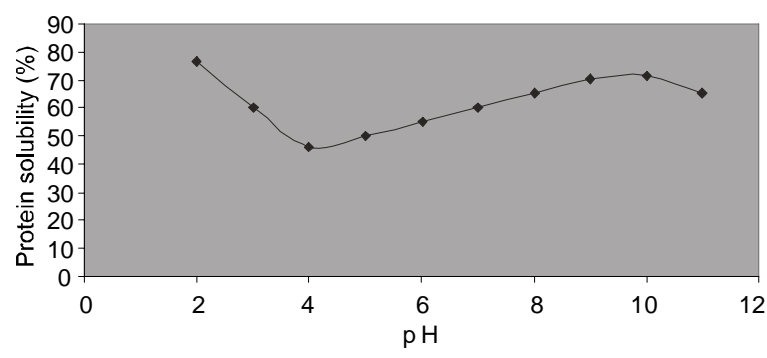

Fig.1. Variation in protein solubility with $\mathrm{pH}$.

1989). It is interesting that the present result is similar to that obtained for kidney bean (Olaofe et al., 2010) for minimum solubility (pH 4) and the maximum(10).

With minimum solubility at $\mathrm{pH} 4$, African nutmeg would probably be useful in the formulation of protein rich carbonated beverages (Ogungbenle, 2003) and low acid foods such as meat products and milk analogue products (Kinsella, 1979). There is a steady increase in protein solubility after $\mathrm{pH} 4.0$ upto a maximum at $\mathrm{pH} 10$ and after $\mathrm{pH} 10$, there is a drop in the protein solubility. This observation is similar to that of Ige et al. (1984) for conophor seeds and Fagbemi and Oshodi (1991) for full fat fluted pumpkin.

Table 3 presents the amino acid composition of dehulled African nutmeg. The result shows that glutamic acid has the highest value, followed by leucine and aspartic acid, whereas cystine has the least value. Total essential amino acids (313.9 mg/g crude protein) are lower than those of soy bean (444.00 mg/g, Biswas et al.,1991), Adenopus breviflorus benth (537.29 mg/g; Oshodi, 1996), pigeon pea $(436.10 \mathrm{mg} / \mathrm{g}$; Oshodi et al., 1993) and dehulled A. africana (796.6 mg/g; Ogungbenle and Omaejalile, 2010). The value $313.9 \mathrm{mg} / \mathrm{g}$ of the sample (Table 4) is moderate and not on the high side of the range $(408-588 \mathrm{mg} / \mathrm{g}$ ) of the requirement for infants (FAO/WHO, 1973).

Table 4 reveals the values of essential, non-essential, acidic, basic, and neutral amino acids of African nutmeg. The amount of total amino acids $(648.9 \mathrm{mg} / \mathrm{g}$ ) is lower than those reported by Adeyeye (1997) for the dehulled African yam bean $(917.48 \mathrm{mg} / \mathrm{g}$ crude protein)and cooked walnut (757.1 mg/g protein) reported by Ogungbenle (2009) but higher than those of kidney bean seed (388 mg/g crude protein; Olaofe et al., 2010) and some legumes such as cream coat cowpea (280.9 $\mathrm{mg} / \mathrm{g}$ protein), white coat cowpea (284.2 mg/g protein), red coat scarlet runner bean( $317.8 \mathrm{mg} / \mathrm{g}$ protein), white coat scarlet runner bean(344.3 mg/g protein) reported by Aremu et al. (2006) and germinated pearl millet 
(464 mg/g protein) reported by Adeyeye (2009) but higher than $327 \mathrm{mg} / \mathrm{g}$ protein reported for kersting's groundnut (Aremu et al., 2006).

The value of total non-essential amino acids $(335.0 \mathrm{mg} / \mathrm{g}$ protein) is comparable with that of African yam bean (327 mg/g protein; Adeyeye, 1997) and cooked walnut (312.5 mg/g protein; Ogungbenle, 2009) but lower than that for kidney bean $(407 \mathrm{mg} / \mathrm{g}$ protein; Olaofe et al., 2010). The amount of histidine in African nutmeg is within the required range recommended for infants by FAO/WHO (1985). Thus, if consumed in appropriate

Table 3. The amino acid composition of dehulled African nutmeg (M. myristica)

\begin{tabular}{llc}
\hline \hline Amino acid & $\begin{array}{l}\text { Concentration } \\
\text { crude protein } \\
\text { (mg/g) }\end{array}$ & $\begin{array}{c}\text { Infant requirement } \\
\text { range crude protein } \\
\text { (mg/g) }\end{array}$ \\
\hline Lysine* & 33.5 & $53-76$ \\
Histidine* & 21.9 & $18-36$ \\
Arginine* & 42.4 & - \\
Aspartic acid & 72.0 & - \\
Threonine* & 25.4 & $40-50$ \\
Serine & 36.3 & - \\
Glutamic acid & 85.8 & - \\
Proline & 23.3 & - \\
Glycine & 38.0 & - \\
Alanine & 40.0 & - \\
Cystine & 9.1 & $29-60$ \\
Valine* & 36.4 & $44-77$ \\
Methionine* & 9.9 & $29-60$ \\
Isoleucine* & 28.3 & $41-53$ \\
Leucine* & 73.3 & $83-107$ \\
Tyrosine & 30.5 & $58-118$ \\
Phenylalanine* & 42.8 & $58-118$ \\
\hline \hline
\end{tabular}

FAO/WHO (1985); *essential amino acids

Table 4. Percentage of the essential, acidic, basic and neutral amino acids of dehulled African nutmeg (Monodora myristica), (mg/g crude protein)

\begin{tabular}{lcl}
\hline \hline Amino acids & $\begin{array}{l}\text { Crude protein } \\
(\mathrm{mg} / \mathrm{g})\end{array}$ & Percentage \\
\hline $\begin{array}{l}\text { Total amino acid } \\
\text { Total non-essential } \\
\quad \text { amino acid }\end{array}$ & 648.90 & 100 \\
$\begin{array}{l}\text { Total essential amino acid } \\
\quad \text { with histidine }\end{array}$ & 335.0 & 51.60 \\
$\quad$ Total essential amino acid & 313.90 & 48.40 \\
$\quad$ & & \\
$\quad$ without histidine & 292.0 & 44.90 \\
Total Acidic amino acid & 157.80 & 24.30 \\
Total basic amino acid & 97.80 & 15.10 \\
Total neutral amino acid & 393.30 & 60.60 \\
\hline \hline
\end{tabular}

quantity per day, it could supply the missing essential amino acid (histidine) in a regular diet that lacks the amino acid.

Total non-essential amino acids (51.6\%) formed the bulk of the amino acids. The value of total essential amino acids (313.9 $\mathrm{mg} / \mathrm{g}$ protein with histidine) is lower than that of melon seeds $(534.4 \mathrm{mg} / \mathrm{g}$ protein; Olaofe et al., 1994) but higher than that of raw pearl millet (224 mg/g protein; Adeyeye, 2009) while that without histidine ( $292.9 \mathrm{mg} / \mathrm{g}$ protein) is higher than the value of steeped pearl millet (194 mg/g protein; Adeyeye ,2009) soy flour (444 mg/g protein; Paul and Southgate, 1988), and Cajanus cajans (426 mg/g protein; Oshodi et al., 1993). The amounts of total essential and non-essential amino acids indicate that African nutmeg (Monodora myristica) is nutritionally comparable to soy bean, pigeon pea, African yam bean, kidney bean and scarlet runner bean. Total neutral amino acids were $393.3 \mathrm{mg} / \mathrm{g}$ crude protein (60.6\%). Total acidic amino acids were $157.8 \mathrm{mg} / \mathrm{g}$ crude protein (24.3\%) while total basic amino acids were $97.8 \mathrm{mg} / \mathrm{g}$ crude protein (15.1\%) were the least concentrated in the sample.

\section{Conclusion}

It can be concluded that the nutritional status of African nutmeg (Monodora myristica) is comparable with many protein-rich legumes. It also does not have harmful effects when consumed and the high availability of essential amino acids indicate its potential for future supplement/formulation of foods and as alternative source of protein for human consumption.

\section{References}

Adegoke, E., Akinsanya, O.A. 1970. Studies of Nigerian medicinal plants. Journal of West African Science Association, 13: 13-33.

Adeyeye, E.I. 2009. Intercorrelation of amino acid quality between raw, steeped and germinated pearl millet (Pennisetum typhoides) grains. Pakistan Journal of Scientific and Industrial Research, 52: 122-129.

Adeyeye, E.I. 1997. Amino acid composition of six varieties of dehulled African yam (Sphenostylis stenocarpa) bean flour. International Journal of Food Science and Nutrition, 48: 345-351.

Ahmed, M., Uddin, M.B., Akhtar, S., Eun, J.B. 2008. Effect of processing treatments on quality of cerealbased soy bean fortified instant weaning food. Pakistan Journal of Nutrition, 7: 493-496. 
Aletor, V.A., Aladetimi, O.O. 1989. Compositional evaluation of some cowpea varieties and some under-utilized edible legumes in Nigeria. Nahrung, 33: 990-1007.

AOAC, 2005. Official Methods of Analysis of the Association of Official Analytical Chemists, $15^{\text {th }}$ edition. AOAC, Washington DC, USA.

Apata, D.F., Ologhobo, A.D. 1994. Biochemical evaluation of some Nigerian legume seeds. Food Chemistry, 49: 333-338.

Aremu,M.O.,Olaofe,O., Akintayo, E.T. 2006. A comparative study on the chemical and amino acid composition of some Nigerian underutilized legume flours. Pakistan Journal of Nutrition, 5: 34-38.

Aremu, M.O., Olaofe, O., Akintayo, E.T. 2005. Nutritional qualities assessment of the presence of hull in some Nigerian underutilized legume seeds. Bulletin of Pure and Applied Science, 24: 47-52.

Asp, N.G. 1996. Dietary carbohydrates : classification by chemistry and physiology. Journal of Food Chemistry, 57: 9-14.

Awadalkareem, A.M., Mustafa, A.I., Tinay, A.H.E. 2008. Protein, mineral and amino acid profile of sorghum flour as influenced by soy bean protein concentrate supplementation. Pakistan Journal of Nutrition, 7: 475-479.

Beuchat, L.R. 1977. Functional and electrophoretic characteristics of succinylated peanut flour protein. Journal of Agricultural Food Chemistry, 25: 258-261.

Biswas, A.R., Ramaswamy, S., Bapna, J.S. 1991. Chemical composition of Momordica charantia L. fruits. Journal of Agricultural Food Chemistry, 39: 1762-1763.

Coffmann, C.W., Garcia, V.C. 1977. Functional properties and amino acid content of a protein isolated from mung bean flour. Journal of Food Science and Technology, 12: 473-484.

Ejiofor, M.A.N., Onwubuke, S.N., Okafor, J.C. 1998. Developing improved methods of processing and utilization of kernels of Irvingia gabonesis (var. gabonensis and var. excelsa). International Tree Crops Journal, 4: 283-290.

Fagbemi, T.N., Oshodi, A.A. 1991. Chemical composition and functional properties of full fat fluted pumpkin seed flour (Telfairia occidentalis). Nigerian Food Journal, 9: 26-32.

FAO/WHO 1985. Energy and Protein Requirements. Report of Joint FAO/WHO Expert Consultation. FAO Food and Nutrition paper, 51 pp., FAO/WHO,
Rome, Italy.

FAO/WHO, 1973. Protein Quality Evaluation. Report of Joint FAO/WHO Expert Consultations. FAO Food and Nutrition paper, pp. 51, 20-22. FAO/WHO, Rome, Italy.

Ige, M.M. Ogunsua, A.O., Oke, O.L. 1984. Functional properties of the proteins of some Nigerian oil seeds: Canophor seeds and three varieties of melon seeds. Journal of Agricultural Food Chemistry, 32: 822-825.

Inklaar, P.A., Fortuin, J. 1969. Determining emulsifying and emulsion stabilizing capacity of protein meat additives. Journal of Food Technology, 32: 103.

Kinsella, J.E. 1979. Functional properties of soy proteins. Journal of American Oil Chemists Society, 56: 224-258.

Kinsella, J.E. 1976. Functional properties of protein foods. Critical Reviews in Food and Nutrition Science, 1: 217-229.

Lin, M.Y., Humbert, E.S., Susulski, F.W. 1974. Certain functional properties of sunflower meal products. Journal of Food Science, 39: 368-370.

Nzikou, J.M., Muoula-Tsieri, M., Pambou-Tobi, N.P.G., Ndangui, C.B., Kimbonguila, A., Silou, Th., Linder, M., Scher, J., Desobry, S. 2010. Proximate composition and physicochemical characteristics of seed and seed oil from Terminalia catappa L. and the kinetics of degradation of the oil during heating. Australian Journal of Basic and Applied Sciences, 4: 2039-2047.

Okon, B.D. 1983. Studies on the Chemical Composition and Nutritive Value of the Fruits of African Star Apple, M. Sc. Thesis, University of Calabar: 67 pp.

Ogungbenle, H.N., Omaejalile, M. 2010. Functional and anti-nutritional properties, in-vitro protein digestibility and amino acid composition of dehulled Afzelia africana seeds. Pakistan Journal of Scientific and Industrial Research, 53: 265-270.

Ogungbenle, H.N. 2009. Chemical and amino acid composition of cooked walnut flour. Pakistan Journal of Scientific and Industrial Research, 52: 130-133.

Ogungbenle, H.N. 2006. Chemical functional properties of some edible oil seeds. La Rivista Italiana Delle Sostanze Grasse, Marzo, 83: 81-84.

Ogungbenle, H.N. 2003. Nutritional evaluation of quinoa (Chenopodium quinoa) flour. International Journal of Food Science and Nutrition, 54: 153-158.

Olaofe, O., Famurewa, J.A.V., Ekuagbere, A.O. 2010. Chemical and functional properties of kidney bean 
seed flour. International Journal of Chemical Sciences, 3: 51-68.

Olaofe, O., Akintayo, E.T., Adeyeye, E.I., Adubiaro, H.O. 2006. Proximate composition and functional properties of bulma cotton (Bomb capsis) seeds. Egyptian Journal of Food Science, 34: 81-90.

Olaofe, O., Adeyemi, F.O., Adediran, G.O. 1994. Amino acid and mineral composition and functional properties of some oil seeds. Journal of Agricultural Food Chemistry, 42: 878-881.

Oshodi, A.A., Ogungbenle, H.N., Oladimeji, M.O. 1999. Chemical composition, nutritionally valuable minerals and functional properties of bennised (Sesamum radiatum), pearl millet (Pennisetum typhoides) and quinoa (Chenopodium quinoa) flours. Inernational Journal of Food Science and Nutrition, 50: 325-331.

Oshodi, A.A., Ipinmoroti, K.O., Adeyeye, E.I. 1997. Functional properties of some varieties of African yam bean (Sphenostylis stenocarpa) flour. International Journal of Food Science, 48: 243-250.

Oshodi, A.A. 1996. Amino acid and fatty acid compositions of Adenopus breviflorus Benth seed. International Journal of Food Science and Nutrition, 47: 295-298.

Oshodi, A.A., Adeladun, M.O. 1993. Proximate composition, some valuable minerals and functional properties of three varieties of lima bean flour. Inernational Journal of Food Science and Nutrition, 43: 181-185.

Oshodi, A.A., Olaofe, O., Hall, G.M. 1993. Amino acid, fatty acid and mineral composition of pigeon pea (Cajanus cajan). International Journal of Food Science and Nutrition, 43: 187-191.

Oshodi, A.A., Ekperigin, M.M. 1989. Functional properties of pigeon pea (Cajanus cajan) flour. Journal of Food Chemistry, 34: 1-5.

Oyenuga, V.O. 1968. Nigerian Foods and Feeding Stuffs, $3^{\text {rd }}$ edition. Ibadan University Press, Ibadan, Nigeria.

Paul, A.A., Southgate, D.A.T. 1988. McCance and Widdowson's The Composition of Foods, $4^{\text {th }}$ edition. The Royal Society of Chemistry, HMSO, London, UK.

Pearson, D. 1976. The Chemical Analysis of Foods, $7^{\text {th }}$ edition. Churchhill, Livingstone, London, UK.

Sathe, S.K., Deshpande, S.S., Salunkhe, D.K. 1982. Functional properties of lupin (Lupinus mustabilis) seed protein and protein concentrates. Journal of Food Science, 47: 491-497.

Sathe, S.K., Salunkhe, D. K. 1981. Functional properties of the great northern bean (Phaseolus vulgaris L.): proteins, emulsion, foaming, viscosity, and gelation properties. Journal of Food Science, 46: 71-76.

Spackman, D.H., Stein, W.H., Moore, S. 1958. Automatic recording apparatus for use in the chromatography of amino acids. Analytical Chemistry, 30: 11901206.

Temple, V.J., Odewumi, L., Joseph, K. 1991. Soy beans and soy bean based diets. Proceedings of the $3^{\text {rd }}$ Regional Workshop on Rural Development. JOS, $31^{\text {st }}$ July-2 ${ }^{\text {nd }}$ August, 1991, pp. 45-50. 